\title{
Human Papillomavirus type distribution in invasive cervical cancer in Uganda
}

\author{
Michael Odida1,2, Silvia de Sanjosé3 ${ }^{3}$, Wim Quint ${ }^{4}$, Xavier F Bosch ${ }^{3}$, \\ Joellen Klaustermeier ${ }^{3}$ and Elisabete Weiderpass*2,5,6
}

\begin{abstract}
Address: ${ }^{1}$ Department of Pathology, Faculty of Medicine, Makerere University, Kampala, Uganda, ${ }^{2}$ Department of Medical Epidemiology and Biostatistics, Karolinska Institutet, Stockholm, Sweden, ${ }^{3}$ Unit of Infections and Cancer, Catalan Institute of Oncology, Barcelona, Spain, ${ }^{4}$ DDL Diagnostic Laboratory, Voorburg, The Netherlands, ${ }^{5}$ Department of Etiological Research, The Cancer Registry of Norway, Oslo, and Department of Community Medicine, Tromso University, Norway and ${ }^{6}$ Department of Genetic Epidemiology, Samfunded Folkhalsan, Helsinki, Finland

Email: Michael Odida - modida@med.mak.ac.ug; Silvia de Sanjosé - s.sanjose@ico.scs.es; Wim Quint - w.g.v.quint@ddl.nl; Xavier F Bosch - x.bosch@ico.scs.es; Joellen Klaustermeier - jklaustermeier@iconcologia.net; Elisabete Weiderpass* - eliwei@ki.se

* Corresponding author
\end{abstract}

Published: 24 June 2008

BMC Infectious Diseases 2008, 8:85 doi:10.1 186/1471-2334-8-85
Received: 27 February 2008

Accepted: 24 June 2008

This article is available from: http://www.biomedcentral.com/I47/-2334/8/85

(c) 2008 Odida et al; licensee BioMed Central Ltd.

This is an Open Access article distributed under the terms of the Creative Commons Attribution License (http://creativecommons.org/licenses/by/2.0), which permits unrestricted use, distribution, and reproduction in any medium, provided the original work is properly cited.

\begin{abstract}
Background: We conducted a study aiming to describe Human Papillomavirus (HPV) type distribution in invasive cervical carcinoma in Uganda.

Methods: 191 archival cervical carcinoma samples diagnosed in the Department of Pathology, Makerere University in Kampala between 1968 and 1992 were analysed using a sensitive PCRReverse Hybridization Line Probe Assay.

Results: Out of the 186 cases of confirmed invasive cervical cancer in the study paraffin blocks, I 4 were positive for HPV DNA. Specific HPV genotypes were identifiable in 109 cases: HPV 16, $18,31,35,39,44,45,51,52$ and 70 . These occurred as single infections in 105 cases $(96.3 \%)$ and as multiple infections in 4 cases (3.7\%). HPV 16 or 18 accounted for $80 \%(84 / 105)$ of cases with single infection.

Conclusion: The results of this study confirm the role of HPV 16 and 18 in cervical cancer pathogenesis in the Ugandan population. The results suggest that the currently available HPV vaccines against HPV 16 and 18 could possibly prevent the majority of invasive cervical cancers in Uganda.
\end{abstract}

\section{Background}

Clinical and epidemiological studies have clearly established that infections by certain human papillomaviruses (HPVs) types are causally linked to cervical cancer development [1-5]. Among the high risk HPV types, HPV 16 and 18 are recognized as the main causes of invasive cervical cancer and its precursor lesions [3]. These two viral types were found in most cases of invasive cervical cancer from 22 countries around the world [4]. HPV 16 tends to predominate in squamous cell carcinomas whereas HPV 18 often predominate in adenocarcinomas [4,6-8]. Some studies have also shown that there are geographical variations in HPV type distribution $[1,4,9,10]$. Finally, recent data shows that HPV immunization offers the greatest possibility for prevention of cervical cancer and has become an important health priority to many govern- 
ments and health organizations worldwide. HPV vaccines that are currently available include VLPs for HPV 16 and $18[11,12]$ as well as HPV 11 and 6 [13]. However, geographical variations in HPV type distribution might influence the currently available HPV vaccine efficacy. Compared to other continents (such as South America and Asia), there is relatively little information about HPV types in invasive cervical cancer in Africa. We conducted a study aiming to characterize HPV type spectrum in the archival specimens from cervical cancer cases from Uganda population including cases diagnosed over 34 years.

\section{Methods}

191 samples from patients with histological diagnosis of invasive cervical carcinoma from 1968 to 1992 were obtained from the archives of the Department of Pathology, Makerere University in Kampala, Uganda. These samples accounted for less than 5\% of cervical carcinomas diagnosed during the study period. Nine cases $(4.7 \%)$ were from the period of 1968 to $1969,66(34.6 \%)$ cases from 1970-1979, 74 (38.7\%) from 1980-1989 and 42 (22.0\%) were from the period 1990-1992. Until the early nineties, the Department of Pathology received most specimens for histopathology services from all hospitals and health facilities in the country.

Samples were received in formalin, which may not always have been buffered. Tissue specimens were usually processed within 24 hours of their arrival to the hospital, but for a fraction of samples transported from remote parts of the country, longer times may have been required. Samples were selected randomly from the register of Pathology Department starting in 1968; we oversampled of adenocarcinomas (1:1) because of the special interest to compare genotype distribution in the two major histologies of cervical cancer.

When at the testing laboratory, the paraffin embedded tissue blocks were re-embedded in fresh paraffin wax and four sections (sandwich method) were cut for testing under strict conditions to avoid potential contamination. The first and the last sections were stained with Haematoxylin and Eosin (H\&E) to confirm diagnosis and to ascertain the suitability of the tissue to continue for HPV testing. The sections in-between were collected in a screwtop Eppendorf tube for HPV testing. A tissue-free paraffin block was cut after each study block to avoid any HPV carry-over from block to block. A new blade was used for each block and the microtome was cleaned with a vacuum cleaner, Histoclear II and 70\% alcohol. To further control for possible sources of contamination, paraffin blocks containing non HPV related lesions (appendicitis, lung tumour, ovary, lymph node etc.) were included blindly in the process at a ratio of 5\%, and blank paraffin sections were simultaneously tested.

Proteinase K (Sigma) digestion for 16 hours at $56^{\circ} \mathrm{C}$ temperature was used to obtain a tissue lysate containing DNA from the paraffin inner $5 \mu \mathrm{m}$ sections. SPF10 PCR was performed using $10 \mu \mathrm{l}$ of a 1:10 dilution with water of the tissue digest in a final reaction volume of $50 \mu \mathrm{l}$ [14]. The amplified PCR products were tested using a probe hybridization with a cocktail of conservative probes recognizing at least 54 mucosal HPV genotypes in a microtitre plate format for the detection of HPV DNA. Optical densities $\left(\mathrm{OD}_{450}\right)$ were read on a microtitre plate reader. HPV DNA positive samples were subsequently analysed by HPV SPF10-LIPA 25 (version 1: produced at Labo Biomedical Products, Rijswijk, The Netherlands) [14], a reverse hybridization technique that detects 25 high-risk and lowrisk HPV types $(6,11,16,18,31,33,34,35,39,40,42$, 43, 44, 45, 51, 52, 53, 54, 56, 58, 59, 66, 68/73, 70, 74). The sequence variation within the SPF10 primers allows the recognition of these different HPV genotypes, except for the types 68 and 73 as their interprimer regions are identical and cannot be distinguished on this test. After PCR, $10 \mu \mathrm{l}$ of the amplimers was used to perform reverse hybridization for HPV genotype identification. The positive hybridization on the strips is visualized as a purple band by means of a precipitating colour substrate on the probe site. Specimens that were HPV/DNA positive but did not hybridize with any of the 25 probes were coded as HPV type X (unknown type). Amplification of a fragment of the human $\beta$-globin gene was performed in all HPV/ DNA negative samples to assess DNA quality. HPV typespecific distributions were calculated among HPV positive women. All SPF10-LIPA25 PCR detection and typing was performed at the facilities of DDL Diagnostic Laboratories (DDL, Voorburg, Netherlands) and at Institut Català d'Oncologia (ICO, Barcelona). HPV detection was evaluated by histology classification (adenocarcinoma vs. squamous cell carcinoma), year of diagnosis and presence of necrosis in the tissue.

Ethical approval for the reported study was obtained from Ethical Committee at Makerere University, Kampala, Uganda.

\section{Results}

Of the 191 paraffin blocks corresponding each one to a cervical cancer cases, 186 harboured invasive cervical carcinoma cells and, according to protocol, were considered suitable for HPV detection. Five were excluded due to extended necroses seen on the histological slide. 146 were diagnosed as squamous carcinomas, 35 were adenocarcinomas, 3 adenosquamous and two were undifferentiated carcinomas. Out of these, 114 were HPV positive and in $72 \mathrm{HPV}$ could not be detected. All the negative samples 
Table I: HPV/DNA detection by cervical cancer histological types

\begin{tabular}{lccc}
\hline & HPV negative & HPV positive $^{\text {a }}$ & Total \\
\hline Squamous carcinoma & 54 & 92 & 146 \\
Adenocarcinoma & 15 & 20 & 35 \\
Adenosquamous & 1 & 2 & 3 \\
Undifferentiated carcinoma & 2 & 0 & 1 \\
\hline Total & 72 & 114 & 186 \\
\hline
\end{tabular}

a HPV not detected. All these samples were human $\beta$-globin gene negative, and therefore inadequate for HPV determination

${ }^{b}$ All $\beta$-globin gene positive

tested negative for the presence of $\beta$-globin gene indicating a poor quality tissue. Table 1 shows the overall $\beta$ globin gene and HPV positivity results according to histological types. There was no statistical differences between histological type and overall HPV infection (Chi2 $=3.64$, $\mathrm{p}=0.3$ ). There was stability of genotype distribution of HPV 16 and HPV 18 over time, taking into account histology.

Specific HPV types were identifiable in 109 cases, while in the remaining five cases no specific HPV types could be identified (Type X). Ten specific HPV types: 16, 18, 31, 35, $39,44,45,51,52$ and 70 were identified. These occurred as single infections in 105 cases, double infections in three cases and triple infections in one case. Analysis of the HPV genotypes distribution among the HPV positive cases showed that HPV 16 and 18 were the most frequent types, followed in descending order by HPV 45, 31, 35, 51,39 and 52. Table 2 shows the distribution of HPV infections and histological types.

In single infections, type 16 occurred in 51 of the cases, type 18 in 33 cases, type 45 in 11 cases, type 31 in four cases, type 35 and 51 in two cases, types 39 and 52 each in one case. The three double infections were found to be combinations of types $16 / 45,16 / 51$ and $45 / 70$ while the triple infections included the HPV types16/44/52. When the analysis was restricted to the histological types of cervical carcinoma, HPV 16 was the most frequent in squamous cell carcinomas $(47.8 \%$ of cases) while in adenocarcinomas, HPV 18 was the most prevalent type $(50 \%)$. Of the squamous cell carcinomas, 44 of the cases

Table 2: HPV type distribution according to histological types

\begin{tabular}{|c|c|c|c|}
\hline HPV types & Squamous carcinomas & Adenocarcinomas & Total \\
\hline & \multicolumn{2}{|c|}{ Infection with single HPV } & $110(96,5 \%)$ \\
\hline & $\mathrm{N}(\%)$ & $\mathrm{N}(\%)$ & $\mathrm{N}(\%)$ \\
\hline HPV 16 & $44(47.8)$ & $7(35.0)$ & $51(44.7)$ \\
\hline HPV 18 & $21(22.8)$ & $10(50.0)$ & $33(28.8)^{\mathrm{a}}$ \\
\hline HPV 16 or 18 & $65(70.6)$ & $17(85.0)$ & $84(73.7)^{\mathrm{a}}$ \\
\hline HPV 3I & $4(4.3)$ & 0 & $4(3.5)$ \\
\hline HPV 35 & $2(2.2)$ & 0 & $2(1.8)$ \\
\hline HPV 39 & I (I.I) & 0 & I (0.9) \\
\hline HPV 45 & $10(10.9)$ & $\mathrm{I}(5.0)$ & II (9.6) \\
\hline HPV 5 I & I (I.I) & I (5.0) & $2(1.8)$ \\
\hline HPV 52 & $\mathrm{I}(\mathrm{I} . \mathrm{I})$ & 0 & I (0.9) \\
\hline \multirow[t]{2}{*}{ Type X } & $4(4.3)$ & I (5) & $5(4.4)$ \\
\hline & \multicolumn{2}{|c|}{ Infection with multiple HPV } & $4(3.5 \%)$ \\
\hline HPV I6/45 & $\mathrm{I}(\mathrm{I} . \mathrm{I})$ & 0 & $\mathrm{I}(0.9)$ \\
\hline HPV I6/5I & $I(I . I)$ & 0 & $I(0.9)$ \\
\hline HPV $45 / 70$ & $\mathrm{I}(\mathrm{I} . \mathrm{I})$ & 0 & I (0.9) \\
\hline HPV I6/44/52 & $\mathrm{I}(\mathrm{I} .1)$ & 0 & I (0.9) \\
\hline Total & 92 & 20 & $114^{a}$ \\
\hline
\end{tabular}

a Includes two additional cases of adenosquamous carcinomas. 
presented with HPV type 16, 21 of the cases with type 18, 10 with type 45 , four with type 31 , two with type 35 , three single infections with types 39,51 , and 52, three double infections and one triple infection. In the adenocarcinomas, 10 were found to have HPV type 18,7 type 16 , one type 45 , and one type 51. Concurrent CIN lesions were seen in 18 cases with single HPV infections and one case with multiple HPV types. No differences in HPV detection were observed between the cases with and without preneoplastic lesions (Table 3).

\section{Discussion}

This study shows that HPV/DNA was detected in 114 out of 186 invasive cervical cancer samples, giving an overall HPV prevalence of $61.3 \%$ of the samples. If the $\beta$-globin gene results are taken into account, then HPV was detected in $100 \%$ of the samples from which cellular DNA was obtained.

Specific HPV genotypes were identified in 109 cases using the highly sensitive SPF10 LiPA technology. Most of the infections were due to single HPV types with only four cases due to multiple infections. HPV 16 and 18 accounted for more than $70 \%$ of the cases, while the remaining were due to the other HPV types, with HPV 45 constituting a major proportion. In squamous cell carcinomas, single infections due to HPV 16 and 18 occurred in $70 \%$ of cases, while in adenocarcinomas these two types occurred in $85 \%$ of cases. Of particular note is the high proportion of squamous cell carcinomas (10.9\%) due to HPV 45. Almost all infections were high risk HPV types, with exception of two low risk HPV (44 and 70) which were seen as part of multiple infections. There were only 5 samples classified as HPV X (HPV/DNA positive and genotype negative); we hope to be able to genotype these samples in the future. HPV 16 and 18 were the 2 most common types identified throughout the study period indicating viral genotype stability in an era in which HIV started to emerge.

The prevalence of HPV DNA in cervical cancer varies in many studies, with some investigators reporting almost $100 \%[2,4]$. This is probably attributable to the efficient extraction of intact DNA from the fresh cervical scrapes or

Table 3: Multiple HPV genotypes in invasive cervical carcinoma cases with and without concurrent CIN lesions

\begin{tabular}{lccc}
\hline & HPV + ( I type) & HPV + (> I type) & Total \\
\hline No CIN & $87(96.7 \%)$ & $3(3.3 \%)$ & 90 \\
With CIN I/2/3 & $18(94.7 \%)$ & $1(5.3 \%)$ & 19 \\
\hline Total & 105 & 4 & 109 \\
\hline
\end{tabular}

$\mathrm{P}>0.05$ cervical tissues used in these studies. The prevalence of HPV positive samples in our study is relatively low, but higher than that found in cervical cancer cases from Mauritius [15]. Similar low detection rates of HPV in archival cervical tissue have been reported recently from Norway [16].

In our study, all the HPV/DNA negative samples were tested for $\beta$-globin gene. All were found to be $\beta$-globin gene negative, although the $\beta$-globin gene primer used was slightly longer than the very short primer used in the DEIA reaction. Thus, the low detection rate is very likely due to poor quality of the DNA in some archival tissue samples. It has been demonstrated that suboptimal processing of specimens in the histological process such as the use of unbuffered formalin as a fixative, which was common before 1970, may yield DNA that is unsuitable for HPV detection [16]. In a subset of 200 samples from the large international RIS HPV TT study, the HPV negative samples were further explored and $89 \%$ of them were found to be $\beta$-globin gene negative, thus attributing this relatively high rate of HPV negativity to the poor quality of these retrospective samples. It was also found that adenocarcinomas were more likely to be HPV negative than squamous cell carcinomas [17].

HPV 16 and 18 are the major aetiological risk factors for cervical carcinoma. Our overall prevalence of the two major HPV types (16 and 18) was over 70\%, which is similar to the IARC multicentric case-control study by Castellsague et al. [1], the study by Hammouda et al. from Algeria [18] that both used fresh samples and GP5+/6+ PCR assay, as well as the most recently meta analysis of the published literature $[9,10]$. The study of Castellsague et al. [1], which provides pooled data of eight case control studies conducted in North Africa (Algeria, Morocco), South America (Brazil, Paraguay, Peru) and South East Asia (India, Thailand, Philippines), showed HPV 16 prevalence of cervical adenocarcinomas of 42.7\%, HPV 18 at $31.8 \%$ and HPV45 3.8\% [1]. However, regional differences were noticeable with a high prevalence of HPV 16 in North Africa and South America, while in South East Asia there was a high prevalence of HPV 18. A recent study from Mozambique [19] on invasive cervical cancer reported a similar prevalence of HPV 16 (about 47\%) and of HPV 16 and 18 combined (about 71\%) as in our study. Compared with the results of pooled analyses of invasive cervical cancer from different continents $[9,10,20]$, our study presents a lower prevalence of HPV 16 (44.7\%) than in Europe, America, Northern Africa and South Asia but comparable with Sub-Saharan Africa, while the HPV 18 prevalence is higher (28.8\%) than in all regions [9]. Considering the adenocarcinomas only [1], the prevalence of HPV 16 in our study is lower (35.0\%) than in North Africa (72.7\%), South America (71.7\%) and comparable with 
the prevalence in South-East Asia (34.6\%). The prevalence of HPV 18 in adenocarcinomas in our study (50\%) is somewhat lower than in South East Asia, but more than twice higher than in the other regions.

The causes of the regional differences in HPV subtype prevalence need clarification, e.g. the results from Mauritius [15], where only HPV 18 was detected, warrants a follow up study. The proportion of HPV types in the two major histological types of cervical carcinoma, i.e. squamous cell carcinoma and adenocarcinoma have been noted to vary, although HPV 16 tend to predominate in squamous carcinomas and HPV 18 in adenocarcinomas. In the study of Bosch et al. [4] HPV 16 occurred in 51.2\% and $28 \%$ of squamous carcinomas and adenocarcinomas respectively, while the prevalence of HPV 18 was $56 \%$ in adenocarcinomas and $12.1 \%$ in squamous carcinomas. In distinction from Bosch et al. results [4], our data shows a lower prevalence of HPV 16 in squamous cell carcinomas but a higher in adenocarcinomas, and a higher prevalence of HPV 18 in squamous tumours, lower in adenocarcinomas. We also did not observe types 31, 39 and 52 in adenocarcinomas, suggesting that these types may be less commonly associated with risk of adenocarcinomas which is in accordance with previously reported data [1]. The absence of these types was also found by other investigators $[18,21]$ but not by the preliminary data of the RIS HPV TT study [22].

One of the interesting findings of our study was the five cases in which the samples were positive for HPV, but specific HPV genotypes could not be identified. This raises the possibility that there may be some unidentified HPV types or that some additional HPV types could have a wider range of probes. In a study in Mozambique [23], HPV specific types could not be identified in $19 \%$ of the HPV positive cases, and this failure was attributed to the limited number of HPV specific probes used.

Multiple infections were seen in only four HPV positive cases (3.5\%) in this study. This is similar to some previous studies where the prevalence varied from $2.5 \%$ in Spain and Columbia [5], 3.9\% in Thailand [6], 4.3\% in Brazil [24], 7.9\% in Morocco [25], and $12.9 \%$ in women with squamous tumour in Peru [26]. However, much higher rates were also reported by other workers, from $19.3 \%$ in Paraguay [27], 32.2\% in Korea [28], 32\% in Costa Rica [29] and 34.3\% in Mozambique [30]. These differences could be due to underlying prevalence of multiple infections in the various populations or to differences in the methods used in detection and diagnosis [31].

Whether multiple HPV infections are involved in cervical cancer pathogenesis is rather unclear. Herrero et al. found that the risk of cervical cancer associated with HPV 16 alone is similar or greater than the risk associated with multiple infections (HPV 16 plus other HPV) [29]. The results of Lee et al. found multiple infections associated with increased cervical cancer risk [32]. Although the number of cases in our study is rather small, the results have some important implications. If the HPV vaccines under trial containing 16 and 18 antigens are close to $100 \%$ efficacy $[11,13]$, then one could assume that about $70 \%$ of cervical cases would be prevented by the use of the vaccine. It also raises the question whether other HPV types should be included in future HPV vaccines. This is of concern because of multiple infections or infection with other common HPV genotypes which could account for $5 \%$ to $10 \%$ of cervical cancer cases. The results of our study are in agreement with previous reports by Hammouda et al. [18], and Castellsague et al. [1].

Our study had a number of strengths. The method we used is sensitive and has high efficacy in comparison with other methods using other general HPV primer sets [14]. In addition, extreme precautions were undertaken to avoid contamination, and stringent SOP (standard of procedures) were applied throughout the study. To avoid false positive results, controls consisting of non-tumour tissue blank paraffin sections and other negative control samples were simultaneously tested in each of the different steps of analysis.

One limitation of our study was the relatively small number of cases tested. Since the specimens came from different parts of the country, the duration of fixation were not uniform and could have contributed to some cases being negative for HPV. In addition, the use of non buffered formalin could also have deteriorated the DNA, resulting in false negative results.

In our study we did not have information on HIV serology. HIV infection is a risk factor for pre cervical cancer lesions [33,34] and also probably for invasive cervical cancer [34], although some earlier studies did not find any associations [35]. Patients with HIV seem to have infections with a broader spectrum of HPV types other than HPV 16, and more prone to simultaneous multiple HPV infections. The prevalence of HIV in Uganda could have been as high as $20 \%$ during part of the time when the samples were collected. This is based on HIV seroprevalance among pregnant women which rose from $10 \%$ in 1985 to around 30\% in 1990-1992 [36]. Although this is a very high rate of HIV, we did not detect in our samples a different HPV genotype distribution of the most frequent types, neither a higher number of multiple infections. 


\section{Conclusion}

The results of our study show that the HPV type distribution can be determined using existing archived biological materials, such as paraffin blocks, allowing evaluating changes over time, and reaffirm the role of HPV in cervical cancer pathogenesis in the Ugandan population. HPV 16 and 18 account for about $75 \%$ of cases while about $20 \%$ are due to other HPV genotypes, and the remaining due to multiple HPV types. The results suggest that more HPV types are yet be identified and recommend that future HPV vaccines be tailored according to local HPV type distribution.

\section{Abbreviations}

CIN: Cervical Intraepithelial Neoplasia; DDL: Delft Diagnostic Laboratories; DEIA: DNA Enzyme Immunoassay; DNA: Deoxyribonucleic acid; H\&E: Haematoxilin and Eosin; HIV: Human Immunodeficiency Virus; HPV: Human papillomavirus; ICO: Institut Catala d'Oncologia; LiPA: Line Probe Assay; OD: Optical density; PCR: Polymerase Chain Reaction; RIS HPV TT: Retrospective International Study on HPV Distribution among Cases of Invasive Cervical Cancer; SOP: Standard of procedures; SPF 10-PCR: Short-Fragment PCR; VLPs: Virus-like particles.

\section{Competing interests}

All authors declare no competing interests in regard to any financial or non-financial relationship.

The founding institutions had no influence on study design, data collection, analysis, interpretation, writing report and decision to submit the paper for publication.

\section{Authors' contributions}

$\mathrm{MO}, \mathrm{EW}$ and SdS were responsible for the concept drafting, full proposal development and getting approval from the ethics committees. MO was responsible for the specimens selection and data file cleaning. JK and WQ were responsible for the HPV DNA detection and quality control analysis. MO, EW, SdS wrote the manuscript and EW and $\mathrm{MO}$ were responsible for the preparation of the manuscript for submission. XFB planned the international collaborative project on HPV in invasive cervical cancer, from which Uganda is one collaborative centre.

\section{Acknowledgements}

We thank Nubia Muñoz, Belen Lloveras, Rebecca Font, Lia Alemany and Sara Tous for their work in the international collaboration on of HPV and invasive cervical cancer project, and Professor Bo Lambert for revising the manuscript. Economical support was received from SIDA/SAREC (Sweden) for the Collaboration between Makerere University and Karolinska Institutet, Stockholm, Sweden; ICRETT fellowship number ICR R 06/139, and unrestricted educational grant from GSK-biologicals. The study is part of the international study RIS HPV TT coordinated at ICO, Barcelona, Spain. The work reported in this paper was undertaken during the tenure of an
Expertise Transfer Fellowship awarded by the International Agency for Research on Cancer to Dr. Weiderpass and Prof. Lambert.

\section{References}

I. Castellsague X, Diaz M, de Sanjose S, Munoz N, Herrero R, Franceschi S, Peeling RW, Ashley R, Smith JS, Snijders PJ, Meijer CJ, Bosch FX: Worldwide human papillomavirus etiology of cervical adenocarcinoma and its cofactors: implications for screening and prevention. J Natl Cancer Inst 2006, 98:303-3I 5.

2. Walboomers JM, Jacobs MV, Manos MM, Bosch FX, Kummer JA, Shah KV, Snijders PJ, Peto J, Meijer CJ, Munoz N: Human papillomavirus is a necessary cause of invasive cervical cancer worldwide. J Pathol 1999, 189:12-19.

3. zur Hausen H: Papillomavirus infections - a major cause of human cancers. Biochim Biophys Acta 1996, I 288:F55-F78.

4. Bosch FX, Manos MM, Munoz N, Sherman M, Jansen AM, Peto J, Schiffman MH, Moreno V, Kurman R, Shah KV: Prevalence of human papillomavirus in cervical cancer: a worldwide perspective. International biological study on cervical cancer (IBSCC) Study Group. J Natl Cancer Inst 1995, 87:796-802.

5. Munoz N, Bosch FX, de Sanjose S, Tafur L, Izarzugaza I, Gili M, Viladiu $P$, Navarro C, Martos C, Ascunce N: The causal link between human papillomavirus and invasive cervical cancer: a population-based case-control study in Colombia and Spain. Int J Cancer 1992, 52:743-749.

6. Chichareon S, Herrero R, Munoz N, Bosch FX, Jacobs MV, Deacon J, Santamaria M, Chongsuvivatwong V, Meijer C], Walboomers JM: Risk factors for cervical cancer in Thailand: a case-control study. J Natl Cancer Inst 1998, 90:50-57.

7. Tase T, Sato S, Wada Y, Yajima A, Okagaki T: Prevalence of human papillomavirus type 18 DNA in adenocarcinoma and adenosquamous carcinoma of the uterine cervix occurring in Japan. Tohoku J Exp Med 1988, I 56:47-53.

8. Wilczynski SP, Bergen S, Walker J, Liao SY, Pearlman LF: Human papillomaviruses and cervical cancer: analysis of histopathologic features associated with different viral types. Hum Pathol 1988, 19:697-704.

9. Smith JS, Lindsay L, Hoots B, Keys J, Franceschi S, Winer R, Clifford GM: Human papillomavirus type distribution in invasive cervical cancer and high-grade cervical lesions: a meta-analysis update. Int I Cancer 2007, I 2 I:62 I-632.

10. Clifford GM, Smith JS, Plummer M, Munoz N, Franceschi S: Human papillomavirus types in invasive cervical cancer worldwide: a meta-analysis. $\mathrm{Br}$ J Cancer 2003, 88:63-73.

II. Harper DM, Franco EL, Wheeler CM, Moscicki AB, Romanowski B, Roteli-Martins CM, Jenkins D, Schuind A, Costa Clemens SA, Dubin G: Sustained efficacy up to $\mathbf{4 . 5}$ years of a bivalent LI virus-like particle vaccine against human papillomavirus types 16 and 18: follow-up from a randomised control trial. Lancet 2006, 367: $1247-1255$.

12. Mao C, Koutsky LA, Ault KA, Wheeler CM, Brown DR, Wiley DJ, Alvarez FB, Bautista OM, Jansen KU, Barr E: Efficacy of human papillomavirus- 16 vaccine to prevent cervical intraepithelial neoplasia: a randomized controlled trial. Obstet Gynecol 2006, 1 07: | 8-27.

13. Villa LL, Costa RL, Petta CA, Andrade RP, Paavonen J, Iversen OE, Olsson SE, Hoye J, Steinwall M, Riis-Johannessen G, Andersson-Ellstrom A, Elfgren K, Krogh G, Lehtinen M, Malm C, Tamms GM, Giacoletti K, Lupinacci L, Railkar R, Taddeo FJ, Bryan J, Esser MT, Sings HL, Saah AJ, Barr E: High sustained efficacy of a prophylactic quadrivalent human papillomavirus types $6 / 11 / 16 / 18 \mathrm{LI}$ virus-like particle vaccine through 5 years of follow-up. $\mathrm{Br} J$ Cancer 2006, 95:|459-|466.

14. Kleter B, van Doorn LJ, ter Schegget J, Schrauwen L, van Krimpen K, Burger M, ter Harmsel B, Quint W: Novel short-fragment PCR assay for highly sensitive broad-spectrum detection of anogenital human papillomaviruses. Am J Pathol 1998, I53:1731-1739.

15. Rughooputh S, Eddoo R, Manraj S, Jeebun N, Greenwell P: Detection of human papillomavirus from archival tissues in cervical cancer patients in Mauritius. J Clin Virol 2006, 35: 173-178.

16. Bertelsen BI, Kugarajh K, Skar R, Laerum OD: HPV subtypes in cervical cancer biopsies between 1930 and 2004: detection using general primer pair PCR and sequencing. Virchows Arch 2006, 449:|4|-|47. 
17. Quint W, Brunsveld JP, Klaustermeier J, de Sanjose S, Lloveras B, Font R, Sanchez GI, Tous S, Molijn A, Munoz N, Bosch FX: Search of the appropriate algorithm for the evaluation of HPV negative blocks of invasive cervical cancer [abstract]. Book of Abstracts. 23rd International Papillomavirus Conference and Clinical Workshop 2006:363.

18. Hammouda D, Munoz N, Herrero R, Arslan A, Bouhadef A, Oublil M, Djedeat B, Fontaniere B, Snijders P, Meijer C, Franceschi S: Cervical carcinoma in Algiers, Algeria: human papillomavirus and lifestyle risk factors. Int J Cancer 2005, I | 3:483-489.

19. Castellsague X, Klaustermeier J, Carrilho C, Albero G, Sacarlal J, Quint W, Kleter B, Lloveras B, Ismail MR, de Sanjosé S, Bosch FX, Alonso $\mathrm{P}$, Menéndez $\mathrm{C}$ : Vaccine-related HPV genotypes in women with and without cervical cancer in Mozambique: Burden and potential for prevention. Int J Cancer 2008, I 22: 1901-1904.

20. Munoz N, Bosch FX, Castellsague X, Diaz M, de Sanjose S, Hammouda D, Viladiu P, Navarro C, Martos C, Ascunce N: Against which human papillomavirus types shall we vaccinate and screen? The international perspective. Int J Cancer 2004 I I I:278-285.

21. An HJ, Kim KR, Kim IS, Kim DW, Park MH, Park IA, Suh KS, Seo EJ, Sung SH, Sohn JH, Yoon HK, Chang ED, Cho HI, Han JY, Hong SR Ahn GH: Prevalence of human papillomavirus DNA in various histological subtypes of cervical adenocarcinoma: a population-based study. Mod Pathol 2005, 18:528-534.

22. de Sanjose S, Quint W, Klaustermeier J, Lloveras B, Brunsveld JP, Font R, Guimera N, Garland S, Nessa A, Oiao YL, Grce M, Clavel C, Lombardi L, Ferrera A, Bhatla N, Jain A, Mariani L, Sasawaga T, Menendez C, Banjo K, Domingo EJ, Ordi J, Chou CY, Chichareon S, Usubutun A, Oliva E, Wright TC, Garcia V, Sanchez GI, Munoz N, Bosch FX: HPV Type Distribution In Invasive Cervical Cancer: The Worldwide Perspective [abstract]. Abstract Book. 24th International Papillomavirus Conference and Clinical Workshop 2007:32.

23. Carrilho C, Gouveia P, Cantel M, Alberto M, Buane L, David L: Characterization of human papillomavirus infection, $\mathrm{P} 53$ and $\mathbf{K i}-$ 67 expression in cervix cancer of Mozambican women. Pathol Res Pract 2003, 199:303-3II.

24. Eluf-Neto J, Booth M, Munoz N, Bosch FX, Meijer CJ, Walboomers JM: Human papillomavirus and invasive cervical cancer in Brazil. Br J Cancer 1994, 69:1 I4-119.

25. Chaouki N, Bosch FX, Munoz N, Meijer C), El Gueddari B, El Ghazi $A$, Deacon J, Castellsague X, Walboomers JM: The viral origin of cervical cancer in Rabat, Morocco. Int J Cancer 1998, 75:546-554.

26. Santos C, Munoz N, Klug S, Almonte M, Guerrero I, Alvarez M, Velarde C, Galdos O, Castillo M, Walboomers J, Meijer C, Caceres E: HPV types and cofactors causing cervical cancer in Peru. $\mathrm{Br}$ J Cancer 200I, 85:966-97I.

27. Rolon PA, Smith JS, Munoz N, Klug SJ, Herrero R, Bosch X, Llamosas F, Meijer C], Walboomers JM: Human papillomavirus infection and invasive cervical cancer in Paraguay. Int J Cancer 2000, 85:486-49l.

28. Huang HJ, Huang SL, Lin CY, Lin RW, Chao FY, Chen MY, Chang TC, Hsueh S, Hsu KH, Lai CH: Human papillomavirus genotyping by a polymerase chain reaction-based genechip method in cervical carcinoma treated with neoadjuvant chemotherapy plus radical surgery. Int J Gynecol Cancer 2004, 1 4:639-649.

29. Herrero R, Hildesheim A, Bratti C, Sherman ME, Hutchinson M, Morales J, Balmaceda I, Greenberg MD, Alfaro M, Burk RD, Wacholder S, Plummer M, Schiffman M: Population-based study of human papillomavirus infection and cervical neoplasia in rural Costa Rica. J Natl Cancer Inst 2000, 92:464-474.

30. Naucler P, Da Costa FM, Ljungberg O, Bugalho A, Dillner J: Human papillomavirus genotypes in cervical cancers in Mozambique. J Gen Virol 2004, 85:2189-2190.

31. Huang LW, Chao SL, Chen PH, Chou HP: Multiple HPV genotypes in cervical carcinomas: improved DNA detection and typing in archival tissues. J Clin Virol 2004, 29:27।-276.

32. Lee SA, Kang D, Seo SS, Jeong JK, Yoo KY, Jeon YT, Kim JW, Park $\mathrm{NH}$, Kang SB, Lee HP, Song YS: Multiple HPV infection in cervical cancer screened by HPVDNAChip. Cancer Lett 2003, 198: 187-192.

33. Moodley JR, Hoffman M, Carrara H, Allan BR, Cooper DD, Rosenberg L, Denny LE, Shapiro S, Williamson AL: HIV and pre-neoplas- tic and neoplastic lesions of the cervix in South Africa: a casecontrol study. BMC Cancer 2006, 6: I35.

34. Gichangi PB, Bwayo J, Estambale B, De Vuyst H, Ojwang S, Rogo K, Abwao H, Temmerman M: Impact of HIV infection on invasive cervical cancer in Kenyan women. AIDS 2003, 17:1963-1968.

35. ter Meulen J, Eberhardt HC, Luande J, Mgaya HN, Chang-Claude J, Mtiro H, Mhina M, Kashaija P, Ockert S, Yu X: Human papillomavirus (HPV) infection, HIV infection and cervical cancer in Tanzania, east Africa. Int J Cancer 1992, 5 I:5I5-52I.

36. UNAIDS/WHO: Epidemiological Fact Sheet on HIVIAIDS and Sexually Transmitted Infections, Uganda. Geneva 1998.

\section{Pre-publication history}

The pre-publication history for this paper can be accessed here:

http://www.biomedcentral.com/1471-2334/8/85/prepub
Publish with Biomed Central and every scientist can read your work free of charge

"BioMed Central will be the most significant development for disseminating the results of biomedical research in our lifetime. " Sir Paul Nurse, Cancer Research UK

Your research papers will be:

- available free of charge to the entire biomedical community

- peer reviewed and published immediately upon acceptance

- cited in PubMed and archived on PubMed Central

- yours - you keep the copyright 